\title{
Principles of the system organization of the provision of the sustainability of the economic frame of a region
}

\author{
Olga A. Chernova \\ Southern Federal University \\ Institute of Economics \\ Rostov-on-Don, Russia \\ chernova.olga71@yandex.ru
}

\author{
Azamat B. Tlisov \\ Russian Presidential Academy of \\ National Economy and Public Administration \\ North Caucasian Institute (Branch) \\ Pyatigorsk, Russia \\ tlisov@mail.ru
}

\author{
Inna A. Mitrofanova \\ Volgograd State Technical University \\ Faculty of Economics and Management \\ Chair of Economics and Management \\ Volgograd, Russia \\ mia05011986@yandex.ru
}

\begin{abstract}
In the article on the basis of the methodology of the system organization of the economy the basic principles of the provision of the sustainability of the economic carcass of the regional economic complex. Their practical realization is based on the interrelated development of the objective, environmental, process and project subsytems of the economic frame. It was shown that the reference points of the frame forming the object sub system should have the opportunity of the transformation of the centripetal tendencies into the centrifugal in the course of the implementation of the innovative projects. In the environmental sub system the most important are institutional and infrastructural factors. The development of the project and process sub systems consist in the provision of the continuity of the reproduction processes in the country. The methological basis of the decision making in administration is renewed. It is connected with the modeling of the economic frame of the economic complex and with the isolation of its points of growth. The example of the agriculture of the South of Russia shows the basic directions of the increase of the sustainability of the economic frame of a region.
\end{abstract}

Keywords - economic frame, region, modernizatoin, integration, system approach, innovations

\section{INTRODUCTION}

In the conditions of the external and internal challenges the creation of the prerequisites of the modernization changes in the region can be possible on the basis of the formation of the creation of the conditions increasing the sustainability of its economic frame. The sustainability of the economic frame is provided by the polycentric type of its structure in which the nuclear elements by means of the reasonable organization of the flows of innovative resources are capable of changing the new growth points by means of which the liquidation of the inter regional asymmetry is achieved [1].

However the market drivers having the "status" of the reference points of the frame are capable of creating a different system order of interregional interactions. Some of them can engender centripetal tendencies in the regional economic space which is reflected in the concentration of the innovative resources in the regional centers on the back of the resource depletion in the periphery. Others can transfer the innovations from the center to the periphery by means of the development and strengthening of the polycentric structure of the economic frame of a territory.

In the first case the sustainability of the construction of the created frame is violated and the opportunities of the self development of various territories of a region are limited. This situation leads to considerable interregional disparities in the level of the social and economic development. In the second case the sustainability is assured by the connectivity of the regional space by means of the polycentric net of the economic actors of various scale and spheres of activity whose interaction is focused on the modernization and development.

That's why the task of the determination of the principles of the system organization of the economic frame becomes significantly important. The reference points of this frame will provide the creation of the modernization changes of the whole territory of the region. The article aimed at the achievement of the parameters mentioned above. 


\section{MATERIALS AND METHODS}

The substantiation of the basic principles of the provision of the sustainability of the economic frame of a region is based on the ideas of G. B. Kleiner about the "system organization of the economy". In compliance with this theory for the creation of the system of this type it is indispensible to have objects, environment, process and project and moreover the basic function is one or several functioning objects [2].

The idea about the object composition of the economic frame was suggested by the authors on the basis of the convergence of the polycentric [3; 4] and quasi corporative approach $[5 ; 6]$ for the research of the territorial organization of the regional economy allowing to consider as the reference points of the frame large corporate structures. The opportunity of the corporate structures to become the reference points of the economic frame is explained by the fact that as $\mathrm{Zh}$. D. Darmilova and $\mathrm{Yu}$. S. Kolesnikov fairly notice they have a serious innovative potential and they are capable of attracting and concentrating considerable financial resources by means of increasing the degree of the innovative attractiveness of a region [7]. Another aspect of the problem is that these structures are focused on the expansion and the development of the integrating relations and that's why they are capable of specifying a particular direction of the balanced development of the regional economy on the basis of the involvement into the implementation of the modernization projects the potential of the small and medium sized business of the periphery [8].

\section{RESULTS AND DISCUSSION}

From the point of view of the mentioned methodological positions it can be said that for the provision of the sustainability of the economic frame of a region its reference points should have the capability of the transformation of the centripetal tendencies into the centrifugal ones by means of the implementation of the innovative projects. In other words for the realization of the modernization changes in the region it is initially necessary to attract and to concentrate investment, labour, organizational, managerial and other resources in the nodal points of the frame which are expected to be growth poles. Further in the given nodal points the gendering of the innovations takes place. They in the process of the increase of the integrating interactions spread on the periphery which leads to the appearance of new growth points also capable of attracting the modernization resources and of engendering innovative impulses (Figure 1).

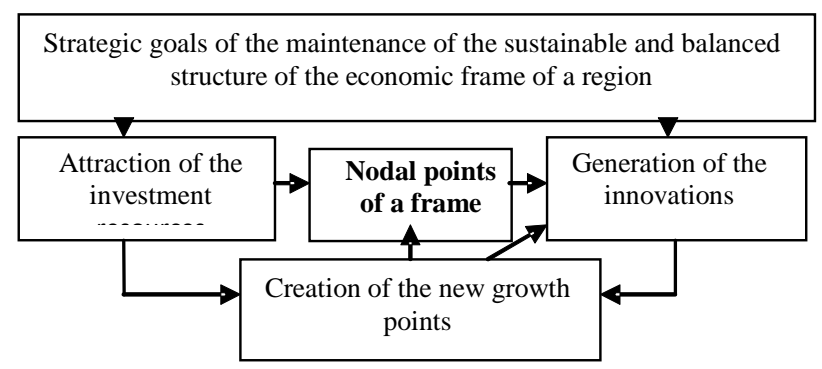

Figure 1. Role of the nodal points in the economic frame of the region.
The opportunity of the attraction of the investment resources by an economic subject for the implementation of the modernization projects is accompanied by its competitive advantages expressed in its innovation potential. In the structure of the innovative potential the resource, environmental and result components can be isolated [9]. The list of possible indices for their assessment is shown in Table 1 .

For the assessment of the measure in which the structure carries out the functions of the generation of the innovative impulses the indices of the manifestation of the synergic and multiplicative regional effects from the point of view of the achievement of the goals of a balanced development in the system center - periphery can be used.

\begin{tabular}{|c|c|}
\hline TABLE I. & $\begin{array}{l}\text { INDICES OF THE ASSESSMENT OF THE INNOVATIVE } \\
\text { OTENITIAL OF A COMPANY }\end{array}$ \\
\hline $\begin{array}{l}\text { Components of the } \\
\text { innovative potential }\end{array}$ & Assessment indices \\
\hline Resource & $\begin{array}{ll}- & \text { Investments into capital funds } \\
- & \text { Capital funds depreciation } \\
- & \text { Share of the technology intensive } \\
\text { equipment in the structure of the capital } \\
\text { funds } \\
-\quad \text { Share of highly skilled workers in their } \\
\text { total number } \\
\text { - }\end{array}$ \\
\hline Environment & $\begin{array}{ll}- & \text { Development of the informational } \\
\text { infrastructure } \\
-\quad \text { Development of the engineering } \\
\text { infrastructure } \\
-\quad \begin{array}{l}\text { Institutional support of the innovation } \\
\text { projects }\end{array}\end{array}$ \\
\hline Result & 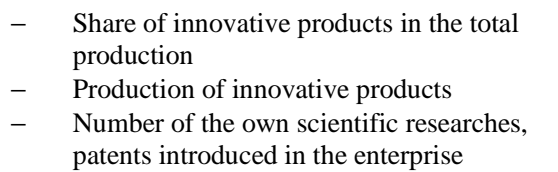 \\
\hline
\end{tabular}

The following indices are expected to be used for the assessment of the level of the generation of the innovative impulses by an economic actor (Table 2).

Such effects are provided mainly by means of the implementation of integrate interactions of different subjects of the regional system engendering a new form of the arrangement of the regional space. The integration interactions lead to the development in the region of joint enterprises, to the creation of the enterprises with a higher level of the technological mode [9-11].

For the assessment of the effects of the generation of innovations by an economic actor the following indices are suggested for use (Table 2).

The designation of an economic subject as a nodal element of the basic frame (together with the provision of the corresponding measure of the state support) is possible if together with a high innovation potential it demonstrates significant positive effects in the regional economic system. 
TABLE II.

INDICES OF THE ASSESSMENT OF THE LEVEL OF THE INNOVATION IMPULSES GENERATION

\begin{tabular}{|l|ll|}
\hline \multicolumn{1}{|c|}{ Types of effects } & \multicolumn{1}{|c|}{ Assessment indices } \\
\hline Synergetic effect & - & $\begin{array}{l}\text { Demand for the local production } \\
\text { GDP at the expense of the corporate } \\
\text { structure functioning } \\
\text { Innovative activity in the region } \\
\text { Multiplicative effect }\end{array}$ \\
\hline & - & $\begin{array}{l}\text { Investments into the region } \\
\text { Share of profitable organizations in the } \\
\text { region }\end{array}$ \\
\hline & - & $\begin{array}{l}\text { Number of the organizations of small } \\
\text { and medium sized business in the } \\
\text { activities joint with the corporation's } \\
\text { industry } \\
\text { Employment rate in the conjoint types } \\
\text { of activities } \\
\text { Indices of the infrastructural } \\
\text { development of a region }\end{array}$ \\
\hline
\end{tabular}

The environment, process and project sub systems are auxiliary in respect to the object sub system of the economic frame of the region.

The environment sub system of the regional economic frame is formed under the impact of the factors of the environment among which the most important are the institutional and infrastructural factors. A considerable institutional heterogeneity is expressed in the conditions of inefficient inertia, quasi market and also informal institutes whose existence is determined by a multistucturality of regional economies with the domination of specific values and relations. This leads to the appearance of barriers on the way of the expansion of the innovations from the center to the periphery. This situation implies the necessity of the harmonization of the processes of the institutional support with the development of an objective sub system. In particular it is spoken about the provision of the internal compatibility of the strategic interests of various economic actors and the growth of their motivation for innovative types of activity.

Another important component of the environmental sub system of the economic frame is a well developed infrastructure of a region (transport, communications and so on). The infrastructure is a main integrating factor of the innovative growth providing the synergetic effect at the expense of the reduction of the transaction costs and the removal of the impediments in the process of the transfer of the resources. When developing an object subsystem of the economic frame it is worth taking into account that a high degree of the wear out of the infrastructural complex leads to the problem of the resource deficit having a negative impact on the speed of the decision making and the realization of the business processes.

The development of the project and process of sub systems of the economic frame in compliance with the principles of the system organization consists in the provision of the continuity of the reproduction processes in the region. Moreover within the modern paradigm of the project management the creation and the development of the economic frame is thought to be implemented in the form of a number of the interrelated projects.
For instance when taking into account the agricultural specialization of the southern Russian regions it is worth mentioning that the development of an object subsystem of the frame can be realized by means of the encouragement of the modernization process in the agriculture. Today in the industry a considerably high dependence on the import of agricultural machines, fertilizers and some types of raw materials persists. That's why even at relatively high indices of the internal economic potential a number of large agricultural companies are incapable of generating considerable synergic and multiplicative effects in the region. Herewith according to the expert's estimates only $1,5 \%$ of large companies producing food products possesses modern machinery and vanguard technologies.

Simultaneously in the South of Russia there exists a positive experience of the center and periphery interactions of the subjects of the small, medium and large business characterize by considerable modernization effects mainly connected with the import replacement policy. The examples of such centers of the business activity are agricultural holdings "Aston", "South of Russia", "Eurodon", "Agrocom", State Company "Tavr", "Novocherkasskiy meat factory" and others. The availability of the elevators, farms, vegetable oil extraction in the companies mentioned above located in the region creates a net structure focused on the modernization development. The functioning of the agricultural holdings has lead to the increase in the last ten years of the farm produciton from $20 \%$ to $30 \%$. Correspondingly the demand for the production of the complementary producing units grows and the employment rate increases as well. All these circumstances allow analyzing all the corporations mentioned above as the nodal points of the economic frame of the region.

For the provision of the sustainability of the economic frame of the region the encouragement of the new forms of the interaction is to be accompanied by the development of the institutional and infrastructural environment. Otherwise the appearance of new object elements will take place in a stable territorial structure of the regional reproduction with the domination of the inertia development pathway. It is worth mentioning that the modern condition of the environmental sub system of the economic frame of the South of Russia is characterized by the presence of the corresponding institutional and infrastructural deficits. Thus for the economy of this macroregion the presence of a big number of institutes typical of obsolete technical modes with the mechanisms of the economic interactions realized on the basis of national, ethnic and relative indices is observed.

The situation in the transport and information infrastructure is equally hard. For instance the density of the highways in the Republic of Kalmykia and in the Astrakhan oblast does not exceed $100 \mathrm{~km}$ per $10000 \mathrm{~km}^{2}$. Correspondingly the cargo turnover in the regions mentioned above is very low despite a high number of agricultural enterprises and farms.

The information infrastructure is insufficiently developed in the whole Russian agriculture. Only $10 \%$ of the agricultural enterprises use modern informational technologies in their activity. The enterprises in the agriculture practically do not 
use such technologies. So in the countries of the European Union more than 50\% farmers use informational and technological systems of various types and in Russia this index is less than 4\%. In conditions of the electronic commerce the backwardness of the informational structure in the agriculture considerably constrains the opportunities for a market competition and as a result inhibits the process of the appearance of innovations in the given sector of the economy of South of Russia.

The integrated character of the measures concerning the sustainability of the economic frame of the region taking into account the development problems mentioned above including its environment sub system determines its involvement into the system of the infrastructural support of all territories of the macroregion taking into account the existing types of the technological mode and available economic potential.

The efficiency of the realization of the measures in the provision of the sustainability of the economic frame of the regional economic complex can be achieved only on the basis of the increase of the role of the state in the support of the self organizing development tendencies of integration interactions of the economic agents of various scale and spheres of the activity. In this respect when we speak about the development benchmarks in the process and project sub systems of the economic frame it is important to provide the vector of the managerial impact on the integration of the modernization resources into the innovative projects of the regional development with an active involvement into such projects the economic potential of the periphery.

\section{CONCLUSION}

The provision of the sustainability of the economic frame of the region in compliance with the principles of the systematic organization implies the necessity of the support of various proportions in the development of its basic components (object, environment, process and project).

In the center of the economic frame the corporate structures capable of the generation of innovations are expected to be found which move the technological level of the subjects interacting with them to a new level. Herewith the sustainability of the economic frame together with the principles of the system organization is reached by means of 1) strengthening of the competitive positions of the reference points of the frame; 2) encouragement of the innovation processes in all the channels of the integration interaction.

In the whole it can be said that such a research will allow actualizing the approaches to the decision making connected with the search of optimal models of the economic frame of a regional economic complex and with the isolation of the nodal points of growth.

\section{Acknowledgment}

The article is funded by the internal grant of the Southern Federal University (YuFU VnGr-07/2017-13) within the project $\ll$ Creation of the system of the decision making in the management of the resource provision of the strategic development of the regions of the South of Russia» of the basic part of the government task of the Ministry for Education and Science of the Russian Federation.

\section{References}

[1] A. K. Dergousova. Mechanism of the formation of the economic frame of the innovative development of a region [Mekhanizm formirovaniya ekonomicheskogo karkasa innovatsionnogo razvitiya regiona], Maikop, 2016, 299 p.

[2] G. B. Kleiner. System Economics as a platform for the development of a modern economic theory [Sistemnaya ekonomika kak platforma razvitiya sovremennoi ekonomicheskoi teorii]. Problems of Economy [Voprosy ekonomiki], 2013, vol. 6, pp. 4-28.

[3] A. A. Mirokhina, S. I. Kutovoy. Conceptual bases of the depositional development of a region on the basis of improvement its spatial and economic structure [Kontseptual'nye osnovy depolyarizirovannogo razvitiya regiona na baze sovershenstvovaniya ego prostranstvennoekonomicheskoi struktury]. Management of economic systems [Upravlenie ekonomicheskimi sistemami], 2012, vol. 9 (45), pp. 26-27.

[4] T. V. Kushnarenko. Taking into account of the phenomenon of mixed strategies of non-oil development of a region [Uchet fenomena mnogoukladnosti $\mathrm{v}$ strategiyakh nesyr'evogo razvitiya regiona]. International scientific research journal [Mezhdunarodnyi nauchnoissledovatel'skii zhurnal], 2015, vol. 9-1 (40), pp. 54-57.

[5] F. Moulaert, A. Mehmood. Analysing regional development and policy: A structural-realist approach. Regional Studies, 2010, vol. 44 (1), pp. 103-118.

[6] A. G. Druzhinin, Yu. S. Kolesnikov, V. N. Ovchinnikov. South of Russia: institutions and strategies of the economy modernization [Yug Rossii: instituty i strategii modernizatsii ekonomiki]. Moscow: University book, 2014. 408 p.

[7] Zh. D. Darmilova, Yu. S. Kolesnikov. Big business and modernization of the economy of Russian regions [Krupnyi biznes i modernizatsiya ekonomiki rossiiskikh regionov]. Terra Economicus, 2008, vol. 4-3, pp. 241-245.

[8] O. A. Chernova, Content of innovative processes in context of regional development [Soderzhanie innovatsionnykh protsessov $\mathrm{v}$ kontekste regional'nogo razvitiya]. Vestnik of Tomsk State University [Vestnik Tomskogo Gosudarstvennogo Universiteta], 2008, vol. 316, pp. 155160.

[9] L. G. Matveeva. Assessment and prediction of the development of the innovative potential in a region: methodology and tools [Otsenka i prognozirovanie razvitiya innovatsionnogo potentsiala $\mathrm{v}$ regione: metodologiya i instrumentarii]. Proceedings of Taganrog radio-technical University [Izvestiya Taganrogskogo radio-tehnicheskogo universiteta], 2016, vol. 4 (59), pp. 92-99.

[10] I. P. Dovbiy, I. V. Mitrofanova, E. G. Russkova, E. A. Shkarupa, V. V. Batmanova, I. A. Mitrofanova, Tendencies, problems and prospects of the balanced and competitive development of agrarian entrepreneurship in Russia. Revista Galega de Economia, 2017, vol. 26-2, pp. 97-112.

[11] I. V. Mitrofanova, A. B. Tlisov, I. A. Mitrofanova, L. M. Shavtikova, Essence of the notion "economic space": political and economic aspect. Regional economy. South of Russia [Regional'naya ekonomika. Yug Rossii], 2016, no. 1, pp. 4-9. 